\title{
Speciation of Chromium in Water Samples with Homogeneous Liquid-Liquid Extraction and Determination by Flame Atomic Absorption Spectrometry
}

\author{
Shiva Dehghan Abkenar, ${ }^{*}$ Morteza Hosseini, Zohreh Dahaghin, ${ }^{\dagger}$ Masoud Salavati-Niasari, ${ }^{\dagger}$ and Mohammad Reza Jamali \\ Department of Chemistry, Islamic Azad University, Savadkooh Branch, Iran.*E-mail: Dehghan54@yahoo.com \\ ${ }^{\dagger}$ Department of Chemistry, Islamic Azad University, Tehran Central Branch, Iran \\ ${ }^{\ddagger}$ Department of Chemistry, Faculty of Science, University of Kashan, Iran \\ ${ }^{\S}$ Faculty of Science, Department of Chemistry, Payame Noor University, Behshahr, Iran \\ Received April 5, 2010, Accepted August 16, 2010
}

\begin{abstract}
A novel method was developed for the speciation of chromium in natural water samples based on homogeneous liquid-liquid extraction and determination by flame atomic absorption spectrometry (FAAS). In this method, $\mathrm{Cr}$ (III) reacts with a new Schiff's base ligand to form the hydrophobic complex, which is subsequently entrapped in the sediment phase, whereas $\mathrm{Cr}(\mathrm{VI})$ remained in aqueous phase. The $\mathrm{Cr}(\mathrm{VI})$ assay is based on its reduction to $\mathrm{Cr}$ (III) by the addition of sodium sulfite to the sample solution. Thus, separation of $\mathrm{Cr}(\mathrm{III})$ and $\mathrm{Cr}(\mathrm{VI})$ could be realized. Homogeneous liquid-liquid extraction based on the $\mathrm{pH}$-independent phase-separation process was investigated using a ternary solvent system (water-tetrabutylammonium ion ( $\mathrm{TBA}^{+}$)-chloroform) for the preconcentration of chromium. The phase separation phenomenon occurred by an ion-pair formation of TBA and perchlorate ion. Then sedimented phase was separated using a $100 \mu \mathrm{L}$ micro-syringe and diluted to $1.0 \mathrm{~mL}$ with ethanol. The sample was introduced into the flame by conventional aspiration. After the optimization of complexation and extraction conditions such as $\mathrm{pH}=9.5,[$ ligand $]=1.0 \times 10^{-4} \mathrm{M},\left[\mathrm{TBA}^{+}\right]=2.0 \times 10^{-2} \mathrm{M},\left[\mathrm{CHCl}_{3}\right]=100.0 \mu \mathrm{L}$ and $\left[\mathrm{ClO}_{4}^{-}\right]=2.0 \times 10^{-2} \mathrm{M}$, a preconcentration factor $(\mathrm{Va} / \mathrm{Vs})$ of 100 was obtained for only $10 \mathrm{~mL}$ of the sample. The relative standard deviation was $2.8 \%(n=10)$. The limit of detection was sufficiently low and lie at ppb level. The proposed method was applied for the extraction and determination of chromium in natural water samples with satisfactory results.
\end{abstract}

Key Words: Chromium, Speciation, Homogeneous liquid-liquid extraction

\section{Introduction}

The chemical and physical properties of a metal species depend very much on its oxidation state; hence, an accurate determination of each species is important for evaluating both the potential risk and benefits of some metals. ${ }^{1}$ In the environment, chromium occurs mainly in the oxidation states (III) and (VI). As is well known, $\mathrm{Cr}$ (III) is essential for plants and animals at trace concentrations, whereas $\mathrm{Cr}(\mathrm{VI})$ is considered to be a species of carcinogen to humans because it easily penetrates the cell wall and exerts its noxious influence in the cell. In recent years, with the extensive use of chromium in colors, electroplating, ceramics, and other industries, $\mathrm{Cr}(\mathrm{VI})$ has become one of the important sources of environment pollution. Therefore, it is necessary for risk assessment, not only to determine the total chromium in the different environmental samples, but also to determine chromium in its different oxidation states. ${ }^{2}$

In order to determine trace or ultra trace inorganic chromium species in an environmental sample, a chemical separation and preconcentration step is often required prior to analysis. For the speciation of chromium, the methods employed are usually based on coprecipitation, ${ }^{3}$ solvent extraction, ${ }^{4,5}$ ion exchange, ${ }^{6}$ cloud point extraction, ${ }^{7-10}$ high-performance liquid chromatographic method $^{11,12}$ and solid phase extraction. ${ }^{13-15}$

The determination of chromium species can be carried out using flame or graphite atomic absorption spectrometry (AAS) ${ }^{16-18}$ spectrophotometric method ${ }^{19}$ inductively coupled plasma-optical emission spectrometry, (ICP-OES) ${ }^{20}$ and inductively coupled plasma-mass spectrometry (ICP-MS), ${ }^{21}$ but accu- racy and sensitivity are often difficult to achieve with direct measurements. The use of prior separation/preconcentration of the samples can aid in improving the determination of $\mathrm{Cr}$ (III) and $\mathrm{Cr}(\mathrm{VI})$ by the above methods.

Flame atomic absorption spectrometry (FAAS) is one of the most extensively used techniques for determination of various elements due to its low cost and great simplicity compared to very sensitive methods such as ICP-MS. Unfortunately, the FAAS technique is specific in respect to chromium, and does not make it possible to determine its forms without initial separation of individual species. Besides, FAAS cannot be directly used to determine individual species at desirable levels of concentrations as its sensitivity is too low. Therefore, a preconcentration and/or separation step is necessary in order to improve the sensitivity and selectivity of FAAS. ${ }^{22}$

Homogeneous liquid-liquid extraction is an excellent method that extracts desired solute existing in the homogeneous solution into the water-immiscible phase, by phase separation phenomenon. In homogeneous liquid-liquid extraction, initially the solution is homogeneous; and there is no interface between the water phase and organic solvent phase. In other words, the surface area of the interface is infinitely large. Accordingly, no vigorous mechanical shaking is necessary. The procedure is simple, rapid, and requires only the addition of the reagents. ${ }^{23}$

Homogeneous liquid-liquid extraction method using a ternary solvent system is developed and applied as a simple and highpowered preconcentration method for the instrumental analysis. ${ }^{24-27}$ In order to obtain homogenous system, various systems exist such as: ion pair system, ${ }^{28}$ surfactant system $^{29}$ and $\mathrm{pH}$ 
dependent system. ${ }^{24}$

Recently, a $\mathrm{pH}$ independent phase separation phenomenon using the ion-pair formation of tetrabutylammonium ion $\left(\mathrm{TBA}^{+}\right)$ and perchlorate $\left(\mathrm{ClO}_{4}^{-}\right)$in homogeneous solution (water/TBA ${ }^{+} /$ chloroform) has been reported. In this method, chloroform is solvated by $\mathrm{TBA}^{+}$and dissolves in water. When $\mathrm{NaClO}_{4}$ is added to the homogeneous solution that consists of water/ $\mathrm{TBA}^{+} /$chloroform, the solvation effect of $\mathrm{TBA}^{+}$is excluded by ion-pair formation of $\mathrm{TBA}^{+}$and $\mathrm{ClO}_{4}^{-}$. Therefore, the chloroform in homogeneous aqueous solution is postulated to form water-immiscible chloroform in aqueous solution by the phase separation. ${ }^{30}$

The Schiff's bases have been extensively studied because of their biological and structural importance, which lies mainly in their specific and selective reactions with metal ions. ${ }^{8,31}$ Almost all metals form 1:1 metal complexes with Schiff's bases. The feature of Schiff's bases give geometric and cavity control of host-guest complexation and modulation of its lipophilicity, and produce remarkable selectivity, sensitivity and stability for a specific ion. The resulting Schiff's base complexes have attracted increasing attention in the area of ionic binding due to their unique properties and reactivity. Schiff's bases are well known to form strong complexes with transition metal ions and have been proposed as spectrophotometric reagents for several metal ions ${ }^{32,33}$ and as ionophore in sensors for determining cations. ${ }^{34,35}$ Few complexes of Schiff's bases with $\mathrm{Cr}$ (III) are known but $\mathrm{Cr}(\mathrm{VI})$ is unable to form complex with Schiff's bases through a ligand charge transfer between the Schiff's bases ligand (highly acceptor ligand) and $\mathrm{Cr}(\mathrm{VI})$ ion (without electron on d orbital). These compounds also have sufficient hydrophobocity to use as a complexing agent in homogeneous liquidliquid extraction.

In spite of the great number of methods stated, $\mathrm{Cr}$ speciation is still matter of concern because procedures without any laborious, expensive, and hazardous treatment are still required. In the present work, a single reaction step was developed for the determination of both $\mathrm{Cr}(\mathrm{III})$ and $\mathrm{Cr}(\mathrm{VI})$. Cr(III) reacts with Schiff's base as a complexing agent in the homogeneous solution, forming a hydrophobic complex, which is subsequently extracted into the water-immiscible phase and separated from the aqueous phase prior to flame atomic absorption spectrometric determination. $\mathrm{Cr}(\mathrm{VI})$ complexes with Schiff's base after its reduction to $\mathrm{Cr}$ (III) by the addition of sodium sulfite to the sample solution. ${ }^{36}$ The proposed method is also applied to the determination of $\mathrm{Cr}(\mathrm{III})$ and $\mathrm{Cr}(\mathrm{VI})$ in water samples.

\section{Experimental}

Apparatus. A Shimadzu model 680 atomic absorption spectrometer equipped with deuterium background correction and Cr hollow cathode lamp as the radiation source was the manufacture's recommendations.

Phase separation was assisted using a centrifuge (centurion scientific Ltd model: 1020D).

The $\mathrm{pH}$ of the solutions was controlled with Metrohm $\mathrm{pH}$ meter model 713.

Reagents and solutions. All the chemicals used were of analytical reagent grade, free from Chromium traces. Stock solu-

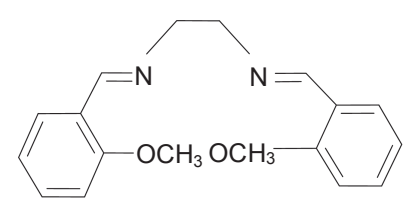

Figure 1. Structure of Schiff's base bis (2-methoxybenzaldehyde) ethylene diimine)

tions of $\mathrm{Cr}$ (III) and $\mathrm{Cr}(\mathrm{VI})$ were prepared by dissolving appropriate amounts of $\mathrm{Cr}\left(\mathrm{NO}_{3}\right)_{2} .9 \mathrm{H}_{2} \mathrm{O}$ and $\mathrm{K}_{2} \mathrm{Cr}_{2} \mathrm{O}_{7}$ (Sigma-Aldrich Ltd.) in double distilled water. Working standard solutions were obtained by appropriate dilution of the stock standard solutions.

Other reagents used were; tetrabutylammonium bromid (Merck), nitric and hydrochloric acid (Merck), sodium hydroxide and sodium perchlorate (Merck). Chloroform and ethanol were of analytical - grade from Merck.

A stock standard buffer solution, $0.1 \mathrm{M}$ was prepared by dissolving appropriate amount of sodium carbonate and hydrochloric acid.

The pipettes and vessels used for trace analysis were kept in $10 \%$ nitric acid for at least $24 \mathrm{~h}$ and subsequently washed four times with deionized water before use.

The chelating agent solution was prepared by dissolving 0.296 g, Schiff's base in $100 \mathrm{~mL}$ of chloroform $99.5 \%$. The Schiff's base bis (2-methoxybenzaldehyde) ethylene diimine) was prepared by interacting ethylene diamine and methoxybenzaldehyde (Figure 1).

Recommended procedure. A $10 \mathrm{~mL}$ homogeneous solution (water/TBA ${ }^{+} /$chloroform) containing $\mathrm{Cr}$ (III) [and/or $\mathrm{Cr}(\mathrm{VI})$ ], chloroform $(100.0 \mu \mathrm{L})$, ligand $\left(1.0 \times 10^{-4} \mathrm{M}\right), \mathrm{TBA}^{+}\left(2.0 \times 10^{-2} \mathrm{M}\right)$ and $5.0 \times 10^{-3} \mathrm{M}$ carbonate buffer $(\mathrm{pH}=9.5)$ were kept in a thermostated bath at $25{ }^{\circ} \mathrm{C}$ for $2 \mathrm{~min}$. At this $\mathrm{pH}$, the recovery of one species $(\mathrm{Cr}(\mathrm{III}))$ is highest and that for the other one $(\mathrm{Cr}(\mathrm{VI}))$ is lowest. Then, the mixture was gently shaken (accordingly, no vigorous mechanical shaking was necessary). Under these conditions, homogeneous solution was obtained. By adding $\mathrm{NaClO}_{4}$ aqueous solution $\left(2.0 \times 10^{-2} \mathrm{M}\right)$ and shaking, a cloudy mixture was formed in the test tube. The mixture was then centrifuged for $5 \mathrm{~min}$ at $3000 \mathrm{rpm}$. The sedimented phase $(90 \mathrm{~mL})$ in the bottom of the conical test tube was separated using a $100 \mathrm{~mL}$ micro-syringe, and diluted to $1 \mathrm{~mL}$ with ethanol. The sample was introduced into the flame by conventional aspiration.

Total chromium was determined as $\mathrm{Cr}$ (III) by the method described above after reducing $\mathrm{Cr}(\mathrm{VI})$ to $\mathrm{Cr}(\mathrm{III})$. The reduction $\mathrm{Cr}(\mathrm{VI})$ to $\mathrm{Cr}(\mathrm{III})$ was performed by the addition of $\mathrm{Na}_{2} \mathrm{SO}_{3}$ $\left(10^{-3} \mathrm{M}\right)$ to the sample solution. Then the concentration of $\mathrm{Cr}$ (VI) was calculated by subtracting the concentration of $\mathrm{Cr}$ (III) from the total chromium concentration. Experimental scheme of the procedure is shown in Scheme 1.

\section{Results and Discussion}

Effect of pH. The separation of metal ions by homogeneous liquid-liquid extraction involves prior formation of a complex with sufficient hydrophobicity to be extracted into the small 


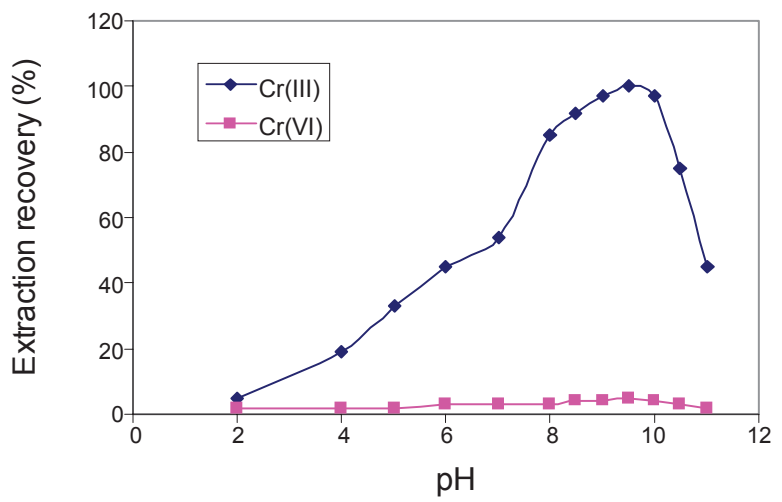

Figure 2. Effect of $\mathrm{pH}$ on the extraction recovery. Conditions: $\mathrm{Cr}$ (III) and $\mathrm{Cr}(\mathrm{VI}), 50.0 \mathrm{ng} \mathrm{mL}^{-1}$; ligand $1.0 \times 10^{-4} \mathrm{M} \mathrm{TBA}^{+} 2.0 \times 10^{-2} \mathrm{M}$; $\mathrm{CHCl}_{3} 100.0 \mu \mathrm{L}$ and $\mathrm{NaClO}_{4} 2.0 \times 10^{-2} \mathrm{M}$.

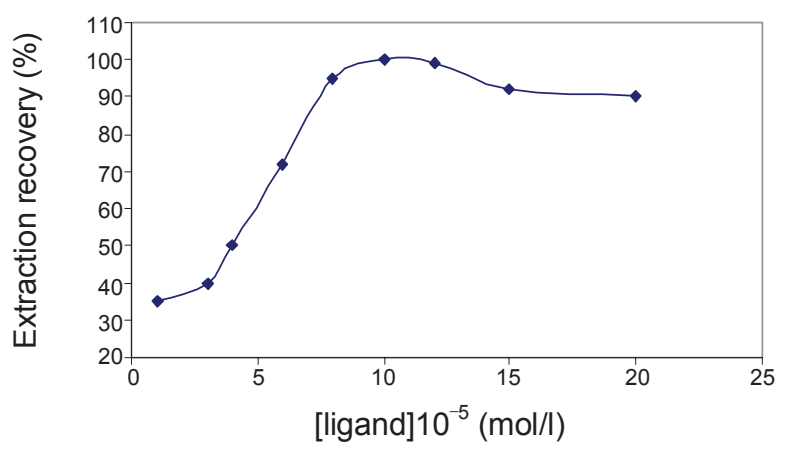

Figure 3. Effect of ligand concentration on the extraction recovery. Conditions: $\mathrm{Cr}$ (III) $50.0 \mathrm{ng} \mathrm{mL}^{-1}$; $\mathrm{TBA}^{+} 2.0 \times 10^{-2} \mathrm{M} ; \mathrm{CHCl}_{3} 100.0 \mu \mathrm{L}$; $\mathrm{NaClO}_{4} 2.0 \times 10^{-2} \mathrm{M}$ and $\mathrm{pH}=9.5$.

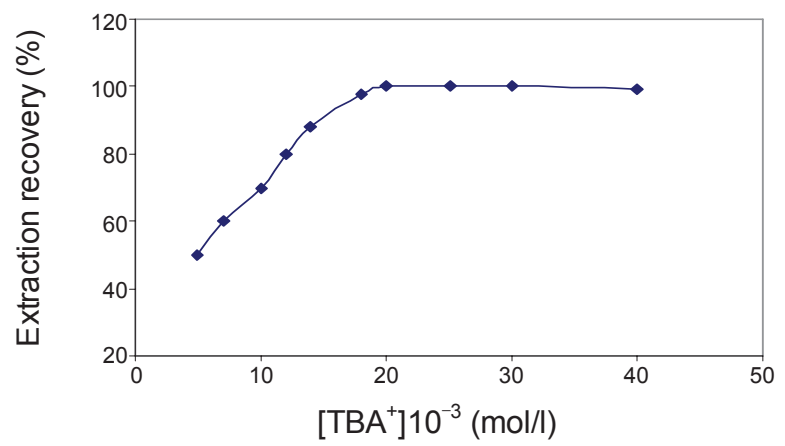

Figure 4. Effect of $\mathrm{TBA}^{+}$concentration on the extraction recovery. Conditions: $\mathrm{Cr}$ (III) $50.0 \mathrm{ng} \mathrm{mL}{ }^{-1}$; ligand $1.0 \times 10^{-4} \mathrm{M} ; \mathrm{CHCl}_{3} 100.0 \mu \mathrm{L}$; $\mathrm{NaClO}_{4} 2.0 \times 10^{-2} \mathrm{M}$ and $\mathrm{pH}=9.5$.

volume of sedimented phase; thus obtaining the desired preconcentration. $\mathrm{pH}$ plays a unique role on metal-chelate formation and subsequent extraction. The effect of $\mathrm{pH}$ on the extraction of chromium from water samples was studied in the $\mathrm{pH}$ ranges of 1 - 12. Figure 2 shows the influence of $\mathrm{pH}$ on the extraction recovery of chromium.

As can be seen, maximum recoveries for $\mathrm{Cr}$ (III) were obtained in the $\mathrm{pH}$ range $9.0-10.0$. While the recoveries for $\mathrm{Cr}$ (III) is quantitative at $\mathrm{pH}=9.5$, the recovery of $\mathrm{Cr}(\mathrm{VI})$ is rather low $(<5 \%)$. Hence, $\mathrm{pH}=9.5$ was chosen as the working $\mathrm{pH}$ and

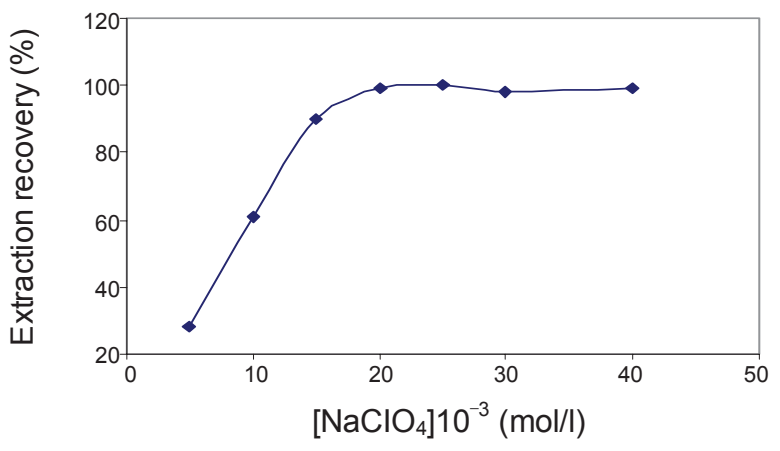

Figure 5. Effect of $\mathrm{ClO}_{4}^{-}$concentration on the extraction recovery. Conditions: $\mathrm{Cr}$ (III) $50.0 \mathrm{ng} \mathrm{mL}^{-1}$; ligand $1.0 \times 10^{-4} \mathrm{M}$; $\mathrm{CHCl}_{3} 100.0 \mu \mathrm{L}$; $\mathrm{TBA}^{+} 2.0 \times 10^{-2} \mathrm{M}$ and $\mathrm{pH}=9.5$.

subsequent extraction was performed in carbonate buffer solution.

Effect of ligand concentration. Under the optimum $\mathrm{pH}$, the effect of the concentrations of ligand on the extraction recovery of $\mathrm{Cr}$ (III) was studied, the results are shown in Figure 3. The extraction recovery increased up to a concentration of $1.0 \times 10^{-4} \mathrm{M}$ and reached a near quantitative extraction efficiency. The concentration level of ligand must remain lower than $1.5 \times 10^{-4} \mathrm{M}$ and the placement of any excess may adversely affect the system performance. This is because of the rise in the background signal in the present of ligand molecules, which presumably are trapped in the water-immiscible phase. Therefore, a concentration of $1.0 \times 10^{-4} \mathrm{M}$ was chosen as optimum concentration.

Effect of $\mathrm{TBA}^{+}$concentration. In order to investigate the optimum amount of $\mathrm{TBA}^{+}$on the quantitative homogeneous liquidliquid extraction of $\mathrm{Cr}(\mathrm{III})$ ion, the extraction of $0.5 \mu \mathrm{g}$ of $\mathrm{Cr}$ (III) from $10 \mathrm{~mL}$ of the sample solutions under the optimal experimental conditions was conducted by varying the concentration of $\mathrm{TBA}^{+}$(Figure 4).

As can be seen, the extraction of $\mathrm{Cr}$ (III) is quantitative above $2.0 \times 10^{-2} \mathrm{M}$ of TBA ${ }^{+}$. Hence, subsequent homogeneous liquidliquid extraction experiments were carried out with $2.0 \times 10^{-2} \mathrm{M}$ of $\mathrm{TBA}^{+}$. At lower concentration, the system remains two phases and the extraction is not quantitative.

Effect of $\mathrm{ClO}_{4}{ }_{4}^{-}$concentration. In order to determine the concentration of $\mathrm{ClO}_{4}{ }^{-}$for quantitative recoveries, the extraction of $0.5 \mu \mathrm{g}$ of $\mathrm{Cr}$ (III) from $10 \mathrm{~mL}$ of the sample solutions under optimum experimental condition was conducted by varying the concentration of $\mathrm{ClO}_{4}^{-}$(Figure 5).

As seen, the extraction of $\mathrm{Cr}$ (III) is quantitative above $2.0 \times$

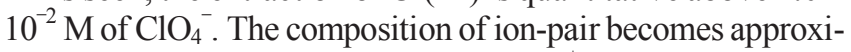
mately $1: 1$ in the neighborhood of $\left[\mathrm{TBA}^{+}\right]=\left[\mathrm{ClO}_{4}^{-}\right]$. Hence, subsequent homogeneous liquid-liquid extraction experiments

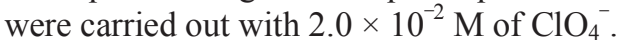

Effect of buffer concentration. The effect of concentration of buffer solution was investigated while other experimental variables remained constant. The results showed that above $1.0 \times 10^{-3} \mathrm{M}$ buffer solution, no obvious variation took place in the extraction yield. Thus, $5.0 \times 10^{-3} \mathrm{M}$ of buffer solution was chosen as the optimum concentration to achieve higher buffering capacity. At lower concentration than $8.0 \times 10^{-4} \mathrm{M}$ of 
buffer solution, the buffering capacity is not sufficient for adjusting $\mathrm{pH}$.

Effect of volume of chloroform. In this extraction method, the concentration factor is strongly dependent on the volume of the sedimented chloroform phase. Figure 6 shows the influence of the volume of added chloroform on the extraction efficiency of $\mathrm{Cr}$ (III)

As can be seen, the extraction of $\mathrm{Cr}(\mathrm{III})$ is quantitative above $100.0 \mu \mathrm{L}$ of $\mathrm{CHCl}_{3}$. Hence, In order to achieve maximum concentration factor, $100.0 \mu \mathrm{L}$ of $\mathrm{CHCl}_{3}$ was added. The concentration factor was calculated as the volume ratio $(\mathrm{Va} / \mathrm{Vs})$ of the aqueous phase (Va) and final volume of sedimented phase (Vs)

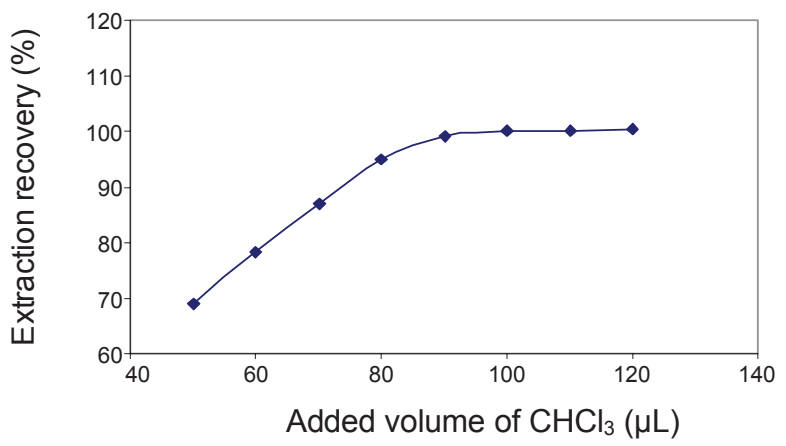

Figure 6. Effect of added volume of chloroform on the extraction recovery. Conditions: $\mathrm{Cr}(\mathrm{III}) 50.0 \mathrm{ng} \mathrm{mL}^{-1}$; ligand $1.0 \times 10^{-4} \mathrm{M}$; $\mathrm{TBA}^{+}$ $2.0 \times 10^{-2} \mathrm{M} ; \mathrm{NaClO}_{4} 2.0 \times 10^{-2} \mathrm{M}$ and $\mathrm{pH}=9.5$.

Table 1. Analytical characteristics of proposed method

\begin{tabular}{cc}
\hline Parameter & Analytical feature \\
\hline Linear range $\left(\mathrm{ng} \mathrm{mL} \mathrm{m}^{-1}\right)$ & $1-700$ \\
Regression equation, $\mathrm{C}\left(\mathrm{ng} \mathrm{mL} \mathrm{L}^{-1}\right)$ & $\mathrm{Y}=2.68 \times 10^{-3} \mathrm{C}+0.008$ \\
Correlation coefficient $(\mathrm{r})$ & 0.9990 \\
Limit of detection $\left.(\mathrm{ng} \mathrm{mL})^{-1}\right)$ & 1.0 \\
Repeatability $\left(\mathrm{RSD}^{a}, \%\right)(\mathrm{n}=10)$ & 2.8 \\
Concentration factor $^{b}$ & 10 \\
\hline
\end{tabular}

${ }^{a} \mathrm{Cr}$ (III) concentration was $20.0 \mathrm{ng} \mathrm{mL}^{-1}$ for which RSD was obtained. ${ }^{b} \mathrm{Con}-$ centration factor is the volume ratio $(\mathrm{Va} / \mathrm{Vs})$ of the aqueous phase $(\mathrm{Va})$ and final volume of sedimented phase (Vs). after phase separation.

Interferences. In the view of the high selectivity provided by FAAS, the only interferences studied were those related to the preconcentration step. To observe these effects, various salts with different concentrations were added to each sample solution containing $50.0 \mu \mathrm{g} \mathrm{L}^{-1}$ of $\mathrm{Cr}$ (III). An ion was considered to interfere when its presence produced a variation in the absorbance of the sample of more than $5 \%$.

Among the interfering ions tested; $\mathrm{Cl}^{-}, \mathrm{NO}_{3}{ }^{-}, \mathrm{ClO}_{4}{ }^{-}, \mathrm{SO}_{4}{ }^{2-}$, $\mathrm{Li}^{+}, \mathrm{K}^{+}, \mathrm{Na}^{+}, \mathrm{Ba}^{2+}, \mathrm{Ca}^{2+}, \mathrm{Mg}^{2+}$, [Ion/Cr (III) (w/w) = 1000] and $\mathrm{Co}^{2+}, \mathrm{Pb}^{2+}, \mathrm{Zn}^{2+}, \mathrm{Cd}^{2+}, \mathrm{Al}^{3+}, \mathrm{Ni}^{2+}, \mathrm{Hg}^{2+}, \mathrm{Ag}^{+}, \mathrm{Fe}^{3+}, \mathrm{Sn}^{2+}, \mathrm{Cd}^{2+}$, $\mathrm{Cu}^{2+}, \mathrm{Ce}^{3+},[$ Ion $/ \mathrm{Cr}(\mathrm{III})(\mathrm{w} / \mathrm{w})=100]$ did not interfere with $\mathrm{Cr}$ (III) determination.

Figures of merit. Table 1 summarized the analytical characteristics of the optimized method, including the linear range, the limit of the detection, the reproducibility, and the concentration factor. The limit of detection, defined as $C_{L}=3 S_{B} / m$ (where $\mathrm{C}_{\mathrm{L}}, \mathrm{S}_{\mathrm{B}}$ and $\mathrm{m}$ are the limit of detection, standard deviation of the blank and slope of the calibration graph, respectively), was $1.0 \mathrm{ng} \mathrm{mL}^{-1}$. The relative standard deviation (RSD) for ten replicate measurements of $20.0 \mathrm{ng} \mathrm{mL}^{-1} \mathrm{Cr}$ (III) was $2.8 \%$.

The concentration factor, the volume ratio $(\mathrm{Va} / \mathrm{Vs})$ of the aqueous phase $(\mathrm{Va}=10 \mathrm{~mL})$ and final volume of sedimented phase $(\mathrm{Vs}=1.0 \mathrm{~mL})$ after phase separation was 10 . Certainly, a preconcentration factor of $100(100 \mu \mathrm{L}$ of chloroform phase $)$ can be obtained from $10 \mathrm{~mL}$ of the homogenous aqueous solution, in combination of this method with other techniques that require low volume of sample such as flow injection analysis (FIA) or electrothermal atomic absorption spectrometry (ETAAS). Preconcentration factor of 100 makes the method applicable for use at sub-ppb level. For comparison, the recent development in separation and determination of chromium are summarized in Table 2. As can be seen, the LOD of this method is comparable to most other methods.

The accuracy of the method was evaluated by analysis in electrothermal atomic absorption spectrometry (ET-AAS). The value obtained (total chromium) by procedure proposed was in excellent agreement with the value obtained by ET-AAS. The achieved result for a river sample using the procedure proposed was $14.00 \pm 0.46 \mathrm{ng} \mathrm{mL}^{-1}(\mathrm{n}=3)$ and the value obtained

Table 2. Comparison of published methods for the determination of chromium

\begin{tabular}{|c|c|c|c|c|}
\hline Matrix & Separation techniques & Determination technique & $\mathrm{LOD}\left(\mathrm{ng} \mathrm{mL} L^{-1}\right)$ & Ref. \\
\hline Natural water & Homogeneous liquid-liquid extraction & FAAS & 1.0 & This study \\
\hline Natural water & Cloud point extraction & Spectrophotometry & 1.04 & {$[37]$} \\
\hline Natural water & Cloud point extraction & FAAS & 0.7 & [38] \\
\hline Natural water & Cloud point extraction & ICP-OES & 1.29 & [39] \\
\hline Industrial water sample & Solid phase extraction & FAAS & $\begin{array}{l}20 \mathrm{Cr}(\mathrm{III}) \\
14 \mathrm{Cr}(\mathrm{VI})\end{array}$ & {$[40]$} \\
\hline Natural water & Solid phase extraction & FAAS & 7.4 Cr(III) & {$[41]$} \\
\hline Natural water & Liquid extraction & FAAS & $\begin{array}{l}\text { 6.6 Cr(VI) } \\
200 \mathrm{Cr}(\mathrm{VI})\end{array}$ & [42] \\
\hline Waste water & Liquid extraction & ICP-MS & 3.0 & [43] \\
\hline Waste water & Ion exchange & ICP-MS & 1.5 & [44] \\
\hline Soil sample & Ion exchange & Spectrophotometry & 10.0 & {$[45]$} \\
\hline
\end{tabular}


Table 3. Determination of $\mathrm{Cr}(\mathrm{III})$ and $\mathrm{Cr}(\mathrm{VI})$ in different water samples

\begin{tabular}{ccccccc}
\hline \multirow{2}{*}{ Sample } & \multicolumn{2}{c}{ Added $\left(\mathrm{ng} \mathrm{mL}^{-1}\right)$} & \multicolumn{2}{c}{ Found $\left(\mathrm{ng} \mathrm{mL}^{-1}\right)$} & \multicolumn{2}{c}{$\operatorname{Recovery~(\% )}$} \\
\cline { 2 - 7 } & $\mathrm{Cr}(\mathrm{III})$ & $\mathrm{Cr}(\mathrm{VI})$ & $\mathrm{Cr}(\mathrm{III})$ & $\mathrm{Cr}(\mathrm{VI})$ & $\mathrm{Cr}(\mathrm{III})$ & $\mathrm{Cr}(\mathrm{VI})$ \\
\hline \multirow{3}{*}{ Tap water } & - & - & $\mathrm{nd}$ & $\mathrm{nd}$ & - & - \\
& 10 & 10 & $9.9\left(2.5^{a}\right)$ & $10.3(2.8)$ & 99.0 & 103.0 \\
\multirow{3}{*}{ River water } & 20 & 20 & $20.4(2.7)$ & $20.3(2.2)$ & 102.0 & 101.5 \\
& - & - & $9.8(2.2)$ & $4.2(3.1)$ & - & - \\
& 10 & 10 & $19.9(3.1)$ & $14.3(2.4)$ & 100.5 & 100.7 \\
\hline
\end{tabular}

${ }^{a} \mathrm{RSD}$ of three replicate experiments

Table 4. Application of the proposed method to the speciation of $\mathrm{Cr}$ in a reference material

\begin{tabular}{ccc}
\hline & $\mathrm{Cr}(\mathrm{III})$ & $\mathrm{Cr}(\mathrm{IV})$ \\
\hline Certified value $\left(\mathrm{ng} \mathrm{mL}^{-1}\right)$ & $26.8 \pm 1.0$ & $22.8 \pm 1.0$ \\
Found (ng mL & $25.9 \pm 0.6$ & $22.6 \pm 0.7$ \\
\hline
\end{tabular}

by ET AAS was $13.74 \pm 0.08 \mathrm{ng} \mathrm{mL}^{-1}$.

Application to samples. The proposed method was applied to the speciation of $\mathrm{Cr}(\mathrm{III})$ and $\mathrm{Cr}(\mathrm{VI})$ in tap water, river water and spiked water samples. Water samples were filtered using a $0.45 \mu \mathrm{m}$ pore size membrane filter to remove suspended particulate matter. For this purpose, $10 \mathrm{~mL}$ of each of the samples were preconcentrated with $100.0 \mu \mathrm{L}$ chloroform following the proposed method. The results are shown in Table 3 Relative error was lower than $3.1 \%$ for $\mathrm{Cr}(\mathrm{III})$ and $\mathrm{Cr}(\mathrm{VI})$. For calibration purposes, the working standard solutions were subjected to the same preconcentration procedure as used for the analyte solutions. Validation of the method was performed using certified reference material BCR 544 for both species. The agreement of the certified values with those obtained using proposed method is acceptable, as can be seen in Table 4 .

\section{Conclusion}

This method is simple, rapid, highly selective and sensitive. Certainly a preconcentration factor of $100(100 \mathrm{~mL}$ of chloroform phase) was obtained from $10 \mathrm{~mL}$ of the homogenous aqueous solution in combination of this method with other techniques that required low volume of sample such as flow injection analysis (FIA) or electrothermal atomic absorption spectrometry (ET-AAS) can be obtained. Preconcentration factor of 100 will make the method very promising for use at sub-ppb level. The proposed method can be applied to determination of trace amount of both chromium species in environmental water samples with satisfactory results.

Acknowledgments. The author thanks the research council at the Savadkooh Branch of Islamic Azad University for financial support.

\section{References}

1. Jen, J. F.; Wu, M. H.; Yang, T. C. Anal. Chim. Acta 1997, 339, 251.
2. Li, Y.; Hu, B.; Jiang, Z.; Wu, Y. Anal Lett. 2006, 39, 809.

3. Krishna, P. G.; Gladis, J. M.; Rambabu, U.; Raob, T. P.; Naidu, G. R. K. Talanta 2004, 63, 541.

4. Subramanian, K. S. Anal Chem. 1988, 60, 11.

5. Karosi, R.; Andruch, V.; Posta, J.; Balogh, J. Microchem J. 2006, $82,61$.

6. Ball, J. W.; McCleskey, R. B. Talanta 2003, 61, 305.

7. Zhu, X. S.; Hu, B.; Jiang, Z. C.; Li, M. F. Water Res. 2005, $39,589$.

8. Shemirani, F.; Dehghan Abkenar, Sh.; Mirroshandel, A. A.; Salavati-Niasari, M.; Kozani, R. R. Anal. Sci. 2003, 19, 1453.

9. Shemirani, F.; Dehghan Abkenar, Sh.; Kozani, R. R.; SalavatiNiasari, M.; Mirroshandel, A. A. Candian J. Anal. Sci. Spec. 2004, $49,31$.

10. Sun, Z.; Liang, P. Microchim Acta 2008, 162, 121.

11. Tang, A. N.; Jiang, D. Q.; Jiang, Y.; Wang, S. W.; Yan, X. P. JChromatogr A 2004, 1036, 183.

12. Borai, E. H.; El-Sofany, E. A.; Abdel-Halim, A. S. Trends Anal Chem. 2002, 21, 741.

13. Anthemidis, A. N.; Zachariadis, G. A.; Koussoroplis, S-JV.; Stratis, J. A. Talanta 2002, 57, 15.

14. Mahmoud, M. E.; Yakout, A. A.; Ahmed, S. B.; Osman, M. M. Journal of Liquid Chromatography \& Related Technologies 2008, 31,2475 .

15. Jiménez de Blas, O.; Chamorro Alonso, M. Analysis 2007, 38, 2091.

16. Wu, T.; Jiang, Y.; Han, D.; Wang, F.; Zhu, J. Microchim Acta 2005 , $159,333$.

17. Ren, Y.; Fan, Z.; Wang, J. Microchim Acta 2006, 158, 227.

18. Kendüzler, E.; Yalçınkaya, Ö.; Baytak, S.; Türker A.R. Microchim Acta 2008, 160, 389.

19. Themelis, D. G.; Kika, F. S.; Economou, A. Talanta 2006, 69, 615.

20. Chen, D. H.; He, M.; Huang, C. Z.; Hu, B. Atomic Spectroscopy 2008, 29, 165.

21. Sun, Y. C.; Lin, C. Y.; Wu, S. F.; Chung, Y. T. Spectrochim ActaPart B At Spectrosc 2006, 61, 230.

22. Hemmatkhah, P.; Bidari, A.; Jafarvand, S.; Milani Hosseini, M. R.; Assadi, Y. Microchim Acta 2009, 166, 69.

23. Takagai, Y.; Maekoya, C.; Igarashi, S. Nippon Kagaku Kaishi. 2000, 4, 291.

24. Igarashi, S.; Arai, T.; Kawakami, T. A. Bunsek kagaku. 1994, 43, 1183.

25. Igarashi, S.; Ide, N.; Takagai, Y. Anal. Chim. Acta 2000, 424, 263.

26. Ghiasvand, A. R.; Shadabi, S.; Mohagheghzadeh, E.; Hashemi, P. Talanta 2005, 66, 912 .

27. Ebrahimzadeh, H.; Yamini, Y.; Kamarei, F.; Shariati, S. Anal. Chim. Acta 2007, 594, 93.

28. Sudo, T.; Igarashi, S. Talanta 1996, 43, 233.

29. Andrade, J. C.; Cuelbas, C. J.; Eiras, S. P. Talanta 1998, 47, 719.

30. Jamali, M. R.; Assadi, Y., Shemirani, F. Sep. Sci. Technol. 2007, 42, 3503 .

31. Dehghan Abkenar, Sh.; Hosseini, M.; Salavati-Niasari, M. Asian. J. Chem. 2008, 20, 4291.

32. Shamsipur, M.; Ghiasvand, A. R.; Sharghi, H.; Naeimi, H. Anal. Chim. Acta 2000, 408, 271. 
33. Dalman, O.; Tüfekci, M.; Nohut, S.; Güner, S.; Karaböcek, S. J. Pharm. Biomed. Anal. 2002, 27, 183.

34. Ganjali, M. R.; Ghesmi, A.; Hosseini, M.; Pourjavid, M. R.; Rezapour, M.; Shamsipur, M.; Salavati-Niasari, M. Sensors and Actuators B. 2005, 105, 334 .

35. Hosseini, M.; Bagheri Sadeghi, H.; Rahimi, M.; Salavati-Niasari, M.; Dehghan Abkenar, Sh.; Alizadeh, K.; Ganjalie, M. R. Electroanalysis 2009, 21, 859.

36. Paleologos, E. K.; Stalikas, C. D.;Tzouwara-Karayanni, S. M.; Karayannis, M. I. Anal. Chim. Acta 2001, 436, 49.

37. Dondurmacioglu, F.; Filik, H. J. Anal. Chem. 2009, 64, 455.

38. Matos, G. D.; dos Reis, E. B.; Costa, A. C. S.; Ferreira, S. L. S.
Microchem J. 2009, 92, 135.

39. Li, J.; Liang, P.; Shi, T. Q.; Lu, H. B. At Spectrosc. 2003, 24, 169.

40. Memon, J. U. R.; Memon, S. Q.; Bhanger, M. I.; Khuhware, M. Y. J. Hazard Mat. 2009, 163, 511.

41. Bayak. S.; Turker, A. R. Microchim. Acta 2005, 149,109.

42. Abliz, S.; Wang, J. D.; Horshida, B. Spectrosc Spect Anal 2005, 25,2082

43. Agrawal, Y. K.; Sharma, K. R. Talanta 2005, 67, 112.

44. Rahman, G. M. M.; Kingston, H. M. S.; Towns, T. G.; Vitale, R. J.; Clay, K. R. Anal. Bioanal. Chem. 2005, 382, 1111.

45. El-Shahawi, M. S.; Hassan, S. S. M.; Othman, A. M.; Zyada, M. A.; El-Sonbati, M. A. Anal. Chim. Acta 2005, 534, 319. 